\title{
The Use of Multimedia in English Teaching*
}

\author{
ZHANG Zhen \\ Leshan Normal University, Leshan, China
}

\begin{abstract}
The 21 st century is an information age as well as knowledge economy age. The rapid development of information technology provides us with advanced teaching means-multimedia. It is true that multimedia has many advantages in English teaching, such as offering more information, saving more time, stimulating students' imagination and creativity, and so on. Although multimedia has many advantages, some scholars suggested that it should not be used blindly. What we should know is that multimedia just only plays an assisting role in English teaching. The thesis consists of four parts. The first part gives a general introduction of multimedia. The second part illustrates the necessity of multimedia in English teaching. The third part elaborates the advantages of multimedia teaching and problems when we use multimedia. The last part gives some strategies on how to use multimedia well.
\end{abstract}

Keywords: multimedia, assisting role, application

\section{Introduction}

Due to the conventional teacher-centered and text-oriented teaching, the phenomenon that English learners have low motivation and low efficiency in English learning is very common. Facing the challenges and demand of new century, English is no longer something carried by a single English teacher, standing in front classroom where only have blackboard, chalk, and tape recorder, transmitting information to a group of students by using traditional teaching ways. Along with the development of computer and information technology, the wide application of multimedia technology has opened up a brand new field for English teaching. But in China, there exists such a contradictory situation in English teaching: People who are good at multimedia have no idea about English teaching while some English teachers know little about multimedia. There are many questions when some English teachers use multimedia. What is multimedia? Why we choose multimedia to assist English teaching? How to make good use of multimedia? These questions will be answered in this thesis.

\section{What Is Multimedia?}

\section{The Definition of Multimedia}

Multimedia: the use of computers to present text, graphics, video, animation, and sound in an integrated way. When we talk about multimedia, a term CALL (Computer Assisted Language Learning) should not be ignored.

\footnotetext{
* Acknowledgements: Sponsorship: This paper is a part of a research program, which is sponsored by Sichuan Foreign Language and Literature Research Center, and the program number is SCWYH14-11.

ZHANG Zhen, master, Foreign Language School, Leshan Normal University.
} 
Since the media can be integrated by using computer, the multimedia has close relation with CALL. Sometimes people even use CALL to stand for multimedia.

Although the definition of multimedia is very simple, making it work is very complicated.

\section{Components of Multimedia}

Multimedia is composed of various components: text, graphics, animation, sound, and video. These components can contribute differentially to the learning of material

Text. It is fundamental element in all multimedia applications. It conveys most information (Vanghan, 2004). We can use ordinary text or various typographic effects for emphasis or clarification in English teaching. In order to catch the reader's attention, teachers can use different font size, color, and style to present information; emphasize a certain word or phrase.

Graphics. It refers to images and pictures, such as chart, diagram, and photograph, which contain no movement. According to Andrew Wright's Book Picture for Language Learning, graphics can stimulate interesting and motivation, improve understanding ability of language, and offer especial reference object and topic (Wright, 2003). Graphics plays a very important role in language teaching process.

Animation. Animation is the rapid display of a sequence of images of 2-D or 3-D artwork or model positions in order to create an illusion of movement. Simply speaking, it ranges scope from the basic graph with a simple motion to a detailed image with complex movements. Assisted by the use of animation, teachers can highlight key knowledge points and heighten students' motivation (Vanghan, 2004).

Sound. It is speech, music, or any other sound that is stored and produced by computers. It has more advantages than tape recorder. In multimedia, teacher can use more vivid and fruitful sound to help students' English learning.

Video. It is the visible part of a television transmission and broadcasts visual images of stationary or moving objects. Compared with animation, video can offer more vivid information. But it will consume more storage space than animation (Vanghan, 2004).

\section{The Setting of Multimedia Classroom}

In traditional classroom, most English teachers are used to using some conventional equipment, such as blackboard, chalk, tape recorders, and so on. However, we can find more modern equipment in a multimedia classroom.

To ensure that readers can obtain a better understanding of multimedia English teaching, an illustration of a typical one-multimedia-PC classroom setting is vital and necessary.

(1) MPC-multimedia personal computer;

(2) VCD/DVD player-video compound disk/digital video disk;

(3) Amplifier and Hi-Fi acoustic system;

(4) Overhead/slide projector;

(5) Screen/curtain;

(6) Projecting apparatus;

(7) The Internet access;

(8) Cassette tape recorder; 
(9) Camera recorder.

\section{The Necessity of Multimedia in English Teaching}

\section{The Necessity of Development of Modern Educational Technology}

Modern educational technology, which is characterized by more information and stronger intuitive, is a combination of modern education and modern technology. The development of modern educational technology not only promotes the development of educational methods and means, but also promotes the development of educational thinking and model. With the rapid development of China's educational undertakings, more and more people pay much attention on multimedia teaching which belongs to modern education. Multimedia appears in school widely, and gradually steps into the front line of education - the classroom teaching. School teaching methods have become more inclined to multi-media teaching methods, and demonstrate its superiority in teaching. We can say that modern educational technology must lead to development of multi-media teaching. Only multimedia teaching can develop and improve the modern education technology well.

\section{The Needs of Quality Education}

There is no doubt, with the global economic development and strong social competition, the State Ministry of Education pays much attention to quality education. How to follow the step of development of quality education in English teaching? The answer is that multimedia is one of the ways to promote the development of quality education. Multimedia English language teaching can enable students to be involved in a variety of sensory organ in the learning process and stimulate the students in the corresponding cortical function area. This stimulation is favor of understanding and memorizing knowledge, produces better learning outcomes, and improves classroom efficiency, thus breaking the traditional English teaching. Multimedia English teaching provides a good educational platform and adds vigor for quality education, enabling students to change and update their thinking from the traditional teaching, thereby enhancing the quality of all aspects.

\section{The Needs of Students' Cognitive Mental}

Cognitive psychology studies have shown that $94 \%$ of the information learned through the visual and auditory access, of which $88 \%$ is obtained through the vision, $12 \%$ through hearing. It is obviously that the visual organs are the most important informed organs of human (WANG, 1992). Under the present circumstances, only the multimedia teaching system can fully mobilize the students' audio-visual and other sensory organs, and thus get the best of the cognitive effect. Therefore, using multimedia teaching is very necessary, especially in English teaching; only effective co-ordination of multimedia can better complete the teaching task.

\section{The Multimedia Teaching}

Many studies have shown that many students are tired of traditional English classes, and are interested in new style learning. They have positive attitude towards computer technology used in the classroom, and such technology does have a positive impact, because multimedia teaching have many advantages over other media in English teaching.

\section{Advantages}

Arousing the students' interest. Famous scientist Albert Einstein had a famous saying: "Interest is the best 
teacher". So the interest has always been seen as the best helper to learn the knowledge. The traditional teaching method is that teachers talk from the beginning to the end with a chalk and a mouth. Such teaching is very single, which makes students lose interest, until weariness. Leo Tolstoy said: "The successful teaching is not to force, but rather to stimulate student's desire" (Tolstoy, 2008, p. 212). In other words, if student have no interest or desire on teaching subject, then, even if the teacher talk how carefully, the results are fruitlessly. Therefore, teachers should try their best to get students to become interest in one topic of knowledge point, and make the students with a strong passion and enthusiasm to participate in teaching. Multimedia is this kind of media which can show a variety of sounds, images, animation, and other effects, firmly grasping the studen's interest. It also can stimulate the students' strong desire to study English actively. Multi-media teaching can not only greatly stimulate students' interest in learning, but also make teaching becomes vivid and lively.

Improving students' self-learning ability. The purpose of teaching in the classroom is not only to impart knowledge to students. The most important thing is teaching students how to learn and making students change from "want me to study" to "I want to learn" in thinking, from passive learning to active learning. Therefore, students are free from the passive learning environment, take initiative at learning, and develop their own self-learning good habits gradually. It also can enable students to tap into a good way of learning English independently, keep the cultivation of motivation and interest in learning English so as to make students really love the English, really free from the passive learning environment in English learning .The use of multimedia will be conducive to transition for students from the traditional passive learning to active state for independent study. For example, teachers can select the appropriate E-work arrangements to the students from the multimedia courseware after class, so that they can complete the relevant extra-curricular work, and send message to the teacher through their own e-mails, the teacher via electronic E-mail marking responses to student. In this way, students can not only see their learning outcomes in the shortest period of time, but also continue stimulating interest in their own learning through the multimedia network.

Improving students' innovative ability. Meanwhile, multi-media teaching can also develop student's ability to innovate. Things need to innovate, Einstein said: "Imagination is more important than knowledge, and is a source of knowledge". In teaching, the teachers should pay attention to tap the imagination of students. To use multimedia can achieve the desired results and find unlimited resources in textbooks.

Cultivating students' communication skills. Chinese students learning English often lack a certain language environment and opportunities for practicing language, but the actual language teaching is often to focus only on words and sentence structures of learning, ignoring its specific application. Thus, many students get a fixed, isolated knowledge points from textbooks, but the ability of using these knowledge points to the real life of the capacity is relatively poor. When encountering with the reality of different occasions, they will be helpless. Through multi-media teaching, we can create real-life scenes in the classroom. It is not only to shorten the distance between teaching and practice and give students the opportunity to use English to communicate, but also to satisfy their curiosity in psychology and stimulate the expression of desire.

Increasing classroom capacity. With only a tiny mouse, teachers can avoid using of multiple exchange of tape recorders, video recorders, overhead projectors, etc., greatly increase the output of information, speed up the pace of the classroom, increase the density of the classroom, and save a lot of time which teachers spend on writing on the blackboard. Multi-media teaching rhythm is adapted to the needs of modernization to meet the 
student's desire for knowledge. It can expand text-related materials. The use of multimedia technologies can make students notice a clear knowledge and a new expansion by huge information capacity which shows by all kinds of media.

\section{Problems}

Multimedia breaks the original traditional model - "blackboard + chalk" model for us to create new modernized teaching methods to overcome the drawbacks of traditional teaching. It changes the dry learning content into the vivid, interesting, visual, audible, and dynamic content. However, teaching English with multi-media has many problems.

Confusion. Some English classes are totally dependent on multi-media, ignoring the role of teachers. Some teachers enter the teaching content into the computer courseware, making the computer courseware as the role of textbooks absolutely in the classroom teaching. What is worse, some teachers have directly brought a CD-ROM courseware for their lessons, or copy other people's courseware overall. It would only demonstrate the results of other people, and just completely ignore the "teaching-centered" teaching thinking, completely change into a multimedia-centered thinking.

Performance on behalf of the lead. The teaching process is that teachers arouse students' enthusiasm and guide students to active learning. Multimedia just only provides a supporting role in the process. But now the teachers use the multi-media presentation to replace the guidance of teachers completely. Some teachers show the teaching materials as many as possible in order to attract the students' interest and make the class vivid. But it was hard for some students to grasp these materials in such a short time. English teachers may bear this proverb in their minds while preparing the lesson: more haste, less speed. Students only pay attention to appreciating the picture, and do not pay attention to what they should really master in the classroom. Students receive a lot via watching in class, without impression and consolidation from the presentation by multimedia.

Lack of special skills. There are many multimedia teachers who just have half-baked knowledge. It is a challenge for teachers to use multimedia equipments sometimes. The preparation and workload of teachers increase virtually. And multimedia teaching requires teachers with multimedia computer operation experience. Owing to traditional educational system, many teachers are not good at computers. There are problems unexpected happening in the observation classes. Because of lack of proficient operation of multimedia, some teachers waste certain time in operation the computer, the unskilled operation on computer would affect the instruction flow, which in turn would de-motive students if it happened frequently in class.

Over-use of multimedia. The advantage of multimedia technology, unfortunately, result in some teachers' dependence on it. In class they fail to show enthusiasm and creation. In some sense, they turn the multimedia classroom into a show stage and what they act in class is nothing but a new generation of button-pusher. Undoubtedly, the lack of creation and enthusiasm makes no sense of multimedia-based teaching. Multimedia it self is not liable for the form and development of teacher's routine work in the multimedia teaching. Because of the teacher's lack of enthusiasm and creation and his or her dependence on the multimedia technology, the teachers act as sole information-giver to the students. The students under such traditional teaching method are still passive and have no chance to have content thinking, critical thinking, and creative thinking of the teachers' lecture. We should remember in a multimedia classroom environment the educational focus is on learning and instructional 
goals instead of the multimedia itself because the multimedia is merely tools or vehicles for instruction.

Lack of interaction between teachers and students. Education is a business and it is imperative to attract students through good human relation skills. The affection builds up between teachers and students plays an important role in class behavior and latter study. However, in the English class it is found the interaction and affection between the teacher and students seemed to be in danger. The teachers in the multimedia classroom are busy with machine operation — computer, DVD player, overhead projector, courseware — which might even get the proficient teachers busy, let alone those unskilled. The teachers will pay much attention to machine rather than students. The tie between the teachers and students becomes loose and it seems to them that teacher is only caring about the machine and they are also focusing on the screen. Thus, the affection, which used to play an important role in class, seems to be dying.

\section{Strategies for Using Multimedia}

\section{Combining Modern Teaching Methods With Traditional Teaching Methods}

There is no doubt that modern teaching methods have many advantages over traditional ones. Compared to traditional textbook or workbook, a multimedia program can provide immediate feedback on the correctness of the learner's response. Nevertheless, traditional teaching methods are still commonly used because of their own strong points. So teachers should combine their strong points with modern teaching methods, which not only raise classroom teaching quality and efficiency, but also improve teaching and learning environment between teachers and students.

\section{Viewing Multimedia as the Assistance to Teaching}

Multimedia features including sound, animation, video, and record allow computers as model skills to help students and teachers assess them. The option to provide guidance only when needed makes it possible for computers to support learning flexibly. Multimedia enables students to manipulate and create material to learn by doing. But when we use computers in the teaching, we should understand they can only assist but cannot take place of all the other teaching methods. It is wrong for the teachers to take no notice of textbooks when they are designing courseware. Now that multimedia can only help English teaching, teachers should get a clear idea of how and when to make good use of them. Application of multimedia technology aims to improve teaching, but teaching is not intended for multimedia. There is no doubt that teaching needs multimedia, but using multimedia does not mean enhancing teaching efficiency. For example, if the teaching can be completed in a few minutes in an ordinary classroom, it is certainly unnecessary to use multimedia. Because of all kinds of media in multimedia technology, sometimes students may concentrate not on teaching contents but on media. If so, students are not able to grasp teaching contents well. That means not every class need multimedia teaching. One important principle is: When simple is best, keep it simple. Therefore, multimedia can only be used as a supplement to classroom English teaching.

\section{Building the Ideal Relationship Between Teachers and Students}

Application of modern teaching methods can make teaching efficient and do part of work instead of teachers. But it is wrong for some people to hold the view that machine can take place of human beings. It is more challenging role for teachers now that the expectations are more complex. In other words, in the information age, 
the role of teachers has evolved, moving from a traditional teaching role (being the "holder" of knowledge) to being "facilitators" (helping students learning the way each learns best) when learners take advantages of the true potential of multimedia as learning tools. At any time teachers' explanation plays an extreme part, which is a language art and cannot be substituted by any teaching methods. Although teaching methods have changed, teaching laws and characteristics of students' development in body and mind remain unchanged. Teachers should play a leading role in the teaching. In the past, students were thought of to be passive knowledge receiver. However, the role of students with learning has changed in the information age. There is a movement towards learner-centered approaches. Thus, students became learning subjects. How actively students participate in the learning situation is an important parameter for the learning environment. One part of the role of students is to actively formulate their own goals for their learning goals. For another thing, students should take a role as a teacher. Being a teacher is beneficial to improve one's own understanding.

\section{Strengthening Teacher Training}

Multimedia assisted English teaching requires teachers with multimedia computer operating experience. It is a challenge for teachers using multimedia because of heavy preparation work and increasing workload. In the light of the problems the teachers should be trained with the use of modern equipments. They should be familiar with the operation. They should be expert in one thing and good at many. They should know well about modern educational theories and techniques.

\section{The Principles of Multimedia-Assisted Teaching}

(1) Scientific principles. Namely, courseware design cannot appear any errors;

(2) Subsidiary principle. We must always adhere to: Although multi-media teaching has many advantages, it is only a supplementary means, and does not substitute for the role of people;

(3) Interactivity principle. More interactivity between teachers and students, students and multimedia, more effective results we will have;

(4) Combination principle. Combine the advantages of modern teaching and the traditional teaching organically.

\section{Conclusion}

In the last several years, the application of multimedia technology in English teaching has become a trend in china, which is especially beneficial to language learning. It is urgent that education needs to be modernized in rapidly society and multimedia is an important aspect in modern education. In order to suit for this kind of need, course reformation and multimedia teaching are sped up in every country, in which it is extremely needed to turn traditional teaching into modern teaching in English teaching. In the future, multimedia technology is likely to be a necessity not only for English teaching but also for teaching for many other subjects. As a device which stimulates and at the same time partners the user's processes of thinking, reasoning, and communicating, the multimedia also has the potential to change these processes. Surely, neither should the practitioners be blindly led by the technological innovation, nor should they deny the function of multimedia in language teaching.

In sum, regardless of the difficulties lying ahead, we must admit that multimedia do make a revolutionary impact on language teaching. To be sure, it is a permanent task for a teacher to do more and deeper studies in the 
application of multimedia. It is no doubt that more practical and effective ways can be worked out to improve English teaching.

\section{References}

Henich, R. (2002). Instructional media and technologies for learning. Beijing: Higher Education Press.

Tolstoy, L., \& CAO, Y. (2008). Childhood, boyhood, and youth. Shanghai: Shanghai literature and Art Publishing House.

Vanghan, T. (2004). Multimrdia: Making it work (8th ed.). Beijing: QingHua University Publishing House.

WANG, A. S. (1992). Cognitive psychology. Beijing: Pecking University Press.

Wright, A. (2003). Picture for language learning. Tianjin: Nan Kai University Publishing House.

ZHONG, Q. Q. (2003). Modern curriculum theory. Shanghai: Shanghai Educational Publishing House. 